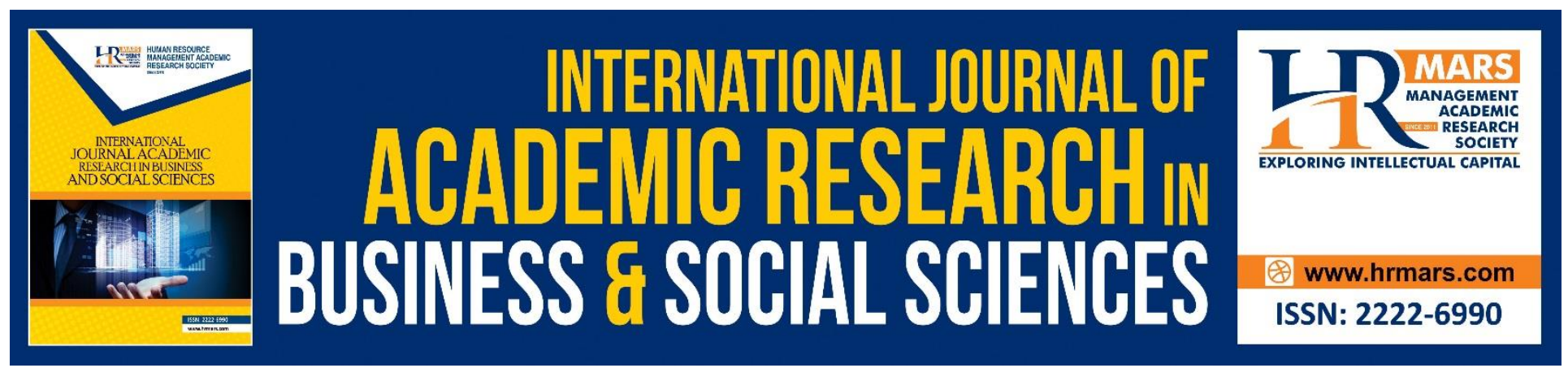

\title{
The Primary Sources of Student Financing in Higher Education Institutions
}

Norhaslinda Daud, Norlia Mat Norwani and Rohaila Yusof

To Link this Article: http://dx.doi.org/10.6007/IJARBSS/v8-i11/5380

DOI: $10.6007 /$ IJARBSS/v8-i11/5380

Received: 04 Nov 2018, Revised: 25 Nov 2018, Accepted: 30 Nov 2018

Published Online: 12 Dec 2018

In-Text Citation: (Daud, Norwani, \& Yusof, 2018)

To Cite this Article: Daud, N., Norwani, N. M., \& Yusof, R. (2018). The Primary Sources of Student Financing in Higher Education Institutions. International Journal of Academic Research in Business and Social Sciences, 8(11), 1888-1895.

Copyright: (C) 2018 The Author(s)

Published by Human Resource Management Academic Research Society (www.hrmars.com)

This article is published under the Creative Commons Attribution (CC BY 4.0) license. Anyone may reproduce, distribute, translate and create derivative works of this article (for both commercial and non-commercial purposes), subject to full attribution to the original publication and authors. The full terms of this license may be seen at: $\underline{\text { http://creativecommons.org/licences/by/4.0/legalcode }}$

Vol. 8, No. 11, 2018, Pg. 1888 - 1895

Full Terms \& Conditions of access and use can be found at http://hrmars.com/index.php/pages/detail/publication-ethics 


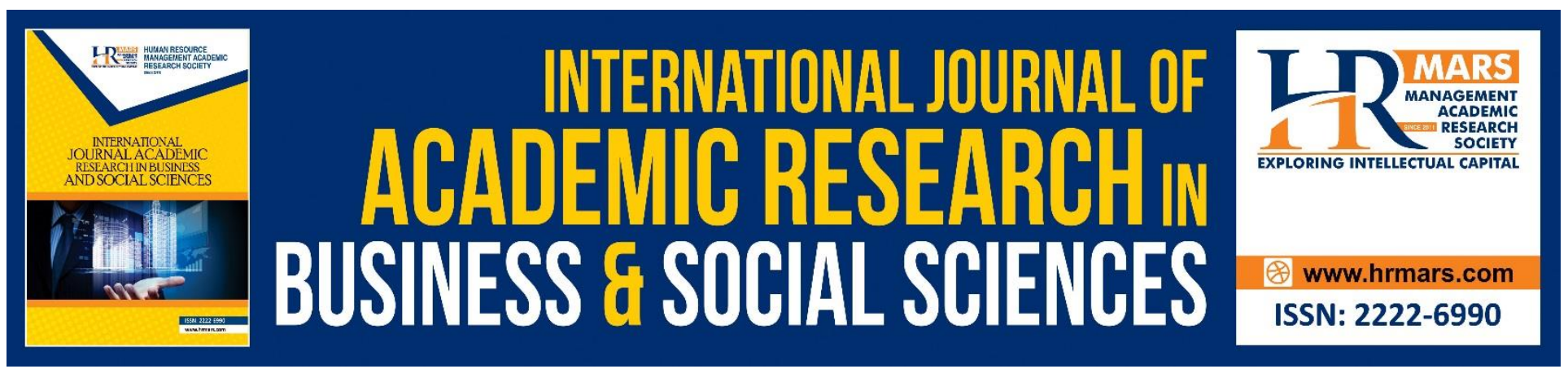

\title{
The Primary Sources of Student Financing in Higher Education Institutions
}

\author{
Norhaslinda Daud ${ }^{1}$, Norlia Mat Norwani and Rohaila Yusof \\ Faculty of Management and Economic, Universiti Pendidikan Sultan Idris, 35900 Tanjong Malim, \\ Perak, Malaysia \\ ${ }^{1}$ Corresponding Author Email: norhaslinda.daud88@gmail.com
}

\begin{abstract}
This study aims to identify the primary sources of student financing in Higher Education Institutions (HEI). This study uses questionnaires as an instrument for data collection method. A total of 480 samples among the undergraduates in HEls responded to the questionnaires. Data were analyzed using the descriptive statistics. The results showed that the main source of respondents financing come from scholarships or loans obtained from government or private body, family, part-time work and savings. Sufficient financing sources will have a positive impact on the financial health of the students on campus.
\end{abstract}

Keywords: Financing, Student, Higher Education Institution

\section{INTRODUCTION}

Money is indispensable in every aspect of our daily lives, in particular to smooth out the increasingly complex financial activities of this modern world. Without money, many needs and services cannot be met. Many people agree that money is only an intermediary for the comfort and safety of life, happiness and wellbeing other than to fulfill the physiological needs of living. Students in higher education require more money to cover the cost of study and living in universities as higher education costs in public and private educational institutions are on the rise. According to Haslina, Naimah and Hamzan (2013), this is due to the impact of cost increases, as well as changes in education orientation and financing policy at a higher level. According to Sarah, Aisyah and Hairunnizam (2015) the cost of higher education today is rising and cannot be fully borne by the government. Apart from spending money for learning purposes such as buying scientific materials, stationery and so on, students are pressured by the rise in prices of essential items such as food and others. Based on the above observation, this study aimed to identify the primary sources of student financing in $\mathrm{HEl}$.

\section{OBJECTIVES OF THE STUDY}

- To identify the primary sources of student financing in Higher Education Institutions 
INTERNATIONAL JOURNAL OF ACADEMIC RESEARCH IN BUSINESS AND SOCIAL SCIENCES

Vol. 8, No. 11, Nov, 2018, E-ISSN: 2222-6990 @ 2018 HRMARS

\section{REVIEW OF LITERATURE \\ Student Financing Resources}

Generally, student financing resources consists of scholarships, education loan, bank loans, contributions from parents or families, and side income from part-time works.

Loans and Scholarships

In order to ensure that all groups receive equal education, the government and non-governmental organizations offer scholarship loans and scholarships for students wishing to pursue higher education, such as the National Higher Education Fund Corporation (PTPTN), Ministry of Education, Malaysia (MOE), Public Service Department (JPA) and Majlis Amanah Rakyat (MARA). However, government funding for higher education in the form of scholarships has been reduced and replaced by student loan. These loans and scholarships are to cover student tuition fees, accommodation and daily expenses.

National Higher Education Fund Corporation (PTPTN)

Referring to PTPTN Strategic Plan 2016-2020 (PTPTN, 2016), PTPTN is an agency under the Ministry of Higher Education Malaysia which was founded on 1st July 1997 under the National Higher Education Fund Corporation Act 1997 (Act 566). PTPTN was established as a government effort to ensure students with financial difficulties can continue their education at HEls. PTPTN offers a loan or financing scheme for example Loan Scheme or Education Financing (SPP), while financial aid is known as the Money Advance Financing (WPP) for the begin of student studies. PTPTN also manages the National Education Savings Scheme (SSPN-i) to help parents plan early financial plans for their children's higher education in the future. According to the official portal of PTPTN (www.ptptn.gov.my, 2017), PTPTN will pay a tuition fee to the HEI for a semester. The balance of SPP loan amounting to thousands of ringgit is given in the student account for the expenses of one semester.

Ministry of Education Malaysia (MOE)

According to official portal (www.moe.gov.my, 2017), MOE provides scholarships and loans for students who are eligible to pursue studies in HEI. Those who are interested need to apply through KPM's official portal and will be contacted for interviews. Students who achieve excellent results in Sijil Pelajaran Malaysia, Higher Education Certificate of Malaysia or Matriculation will most likely be awarded scholarships. Scholarships are deposited into a student bank account on a monthly basis which is called an allowance.

Public Service Department (JPA)

According to the official JPA portal (www.jpa.gov.my, 2017), the JPA has been offering scholarships for study inside and outside the country. All applications can now be made through the official JPA portal and only selected students are offered this scholarship. The amount of scholarships depends on the field of study, type of $\mathrm{HEl}$ and the country concerned. 
Majlis Amanah Rakyat (MARA)

According to MARA's official portal (www.mara.gov.my, 2017), MARA supervised by the Ministry of Rural and Regional Development, there is a Student Scholarship, Education Loan and Student Loan. MARA only offers eligible Bumiputera Malaysians. They can apply through MARA's official portal.

\section{Bank Loan}

Some students make educational loans offered by local banks for failing to get scholarships or loans. There are also students borrowing because of insufficient scholarships or loans. For example, according to the official portal of Malayan Banking Berhad (www.maybank2u.com.my, 2017), Malayan Banking Berhad offers the One Malaysia Education Concern Scheme. This loan scheme is an additional financial aid to students who have received scholarships or educational loans. Only Malaysian undergraduates who are pursuing studies at the first degree level with high CPGA are eligible to apply. The loan amount ranges from RM 2,000.00 to RM 150,000.00 with a fixed interest rate charged.

Parent or Family Help

When financial resources are depleted, students are forced to rely on the help of parents or family members. Difficulty is getting worse if students come from poor families. On the other hand, students who come from middle families are able to provide regular financial assistance to them.

Part-time Work

According to Suhaila, Rabi'atul, Nuzul and Siti (2016) there are groups of students doing part-time work to cover the cost of living. Some students work in shops, supermarkets, stalls and doing business on the internet. Some students engage in the entertainment world by being part-time model, singer or actor.

\section{METHODOLOGY}

According to Lilawati (2013) the methodology of study is defined as a descriptive study using survey methods to obtain information. The target population of this study is centered on HEls from four zones in Peninsular Malaysia. The North, South, West and East Zones was covered. Selection of this location is appropriate to achieve the objective of the study. University Pendidikan Sultan Idris (UPSI), University Teknologi Petronas (UTP), University Teknikal Malaysia Melaka (UTeM), University Multimedia Malacca (MMU), University Putra Malaysia (UPM), University Tenaga Nasional (Uniten), University Malaysia Pahang (UMP) and UCSI University Terengganu are involved according to their respective zones.

The researcher has chosen a purposive sampling method where the population involved is the final year of Bachelor's degree. This group of students is selected because the student has reached maturity in making financial decisions while undergoing studies at $\mathrm{HEI}$. The researcher referred to Krejcie \& Morgan (1970) schedule to determine the size of the sample. Referring to the table, the sample size appropriate for this study was 480 students because the total population was approximately 20,000 students. 
INTERNATIONAL JOURNAL OF ACADEMIC RESEARCH IN BUSINESS AND SOCIAL SCIENCES

Vol. 8, No. 11, Nov, 2018, E-ISSN: 2222-6990 @ 2018 HRMARS

According to Table 1, the respondents' background consisting of gender, age, race, HEI name and CGPA. It is found that female students dominate male students in HEl. For aged, the range is between 20 - 24 and above, this is because all respondents involved are from the final year of the Bachelor's. Respondents consist of various ethnicities in Malaysia. The selection of the same number of respondents from all universities involved is taken to obtain fair and equitable results. All respondents have a CGPA of more than 2.00. It can be concluded that the performance of majority of the respondents belong to the excellent students in $\mathrm{HEI}$.

Table 1 : Respondents Background

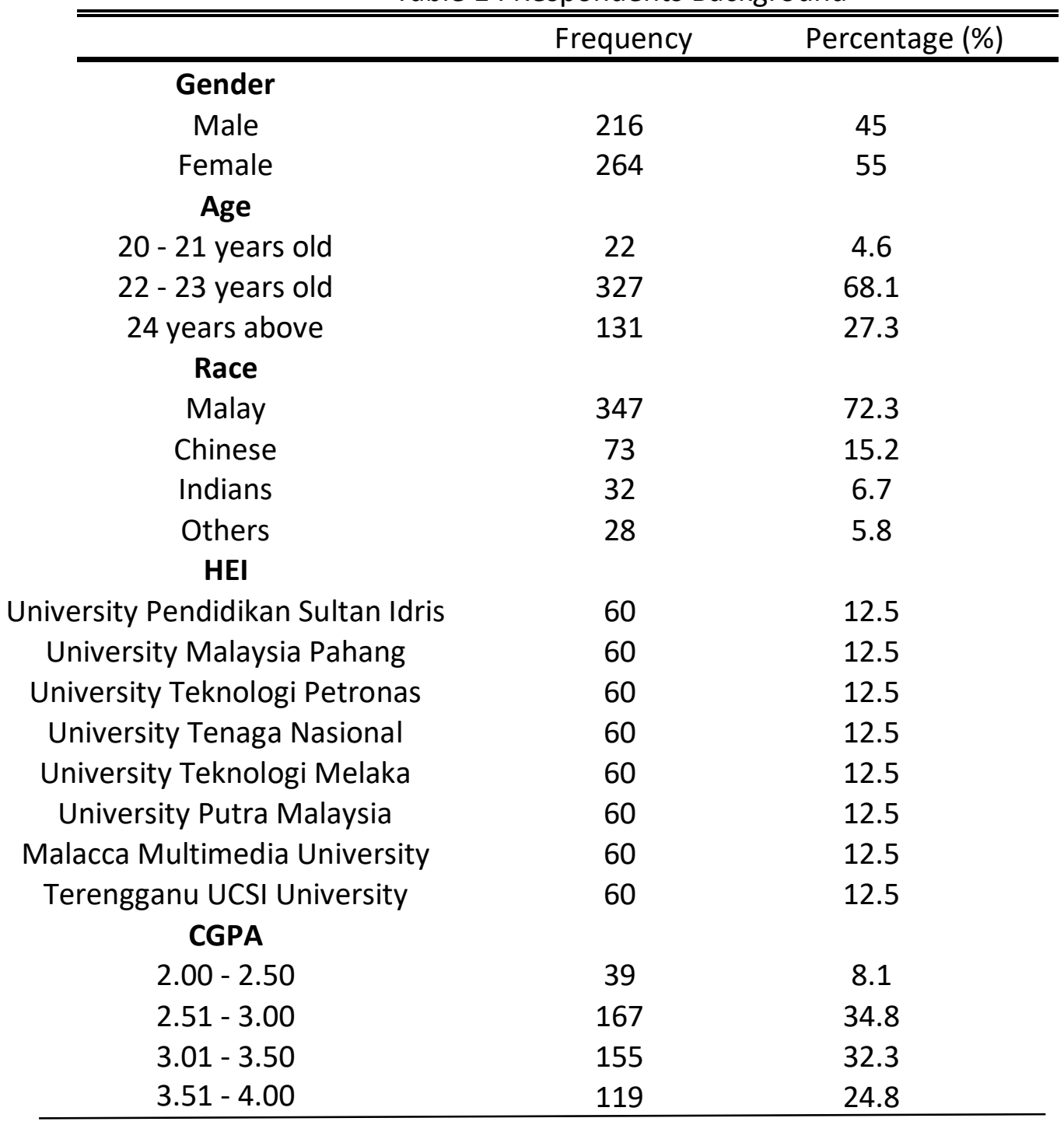

The researcher has chosen the questionnaire as an instrument because this method is an effective measure in collecting many data. In addition, it also saves time, cost and energy. The questionnaire used is modified based on previous research. The items in the questionnaire were considered as relevant for the purpose of this study. 
The items are assessed in terms of reliability and validity before they are distributed to the respondents. Hence, the questionnaire items were formulated based on what has been recognized as valid and subsequently reviewed by six lecturers serving IPTA and IPTS with expertise in the field of research to ensure the structure of the questionnaire, content and language used are accurate.

The results obtained are further illustrated in the form of descriptions and tables to enable readers to understand the findings clearly without requiring long description (Kirkpatrick \& Feeney, 2005).

\section{FINDINGS AND DISCUSSION}

\section{Respondents Financing Resources}

Table 2 shows the financing resources received by the respondents. Of 480 respondents, 276 or $57.5 \%$ received financial assistance from PTPTN, followed by 64 or $13.3 \%$ from the family, 59 or $12.3 \%$ from MARA, 36 or $7.5 \%$ from JPA and 3 or $0.6 \%$ from KPM. A total of 42 people or $8.8 \%$ received funding from other government bodies such as the Sarawak, Sabah and Malacca foundations. It is clear that the majority of respondents expect financial assistance from the government sector.

Table 2 : Respondents Financing Sources

\begin{tabular}{lcc}
\hline \hline & Frequency & Percentage (\%) \\
\hline Families & 64 & 13.3 \\
PTPTN & 276 & 57.5 \\
JPA & 36 & 7.5 \\
KPM & 3 & 0.6 \\
MARA & 59 & 12.3 \\
Others & 42 & 8.8 \\
\hline Total & 480 & 100.0 \\
\hline \hline
\end{tabular}

Referring to Table 3, 386 respondents or $80.4 \%$ responding they received financial assistance from family members comprising parents, older brothers or sisters if the money received was insufficient. Only 94 respondents or $19.6 \%$ did not seek financial assistance from their families.

Table 3 : Respondents Financing Source From Families

\begin{tabular}{ccc}
\hline \hline & Frequency & Percentage (\%) \\
\hline Yes & 386 & 80.4 \\
No & 94 & 19.6 \\
\hline Total & 480 & 100.0 \\
\hline \hline
\end{tabular}

However, there are also some respondents who work while studying at the weekend or middle or end of semester breaks to obtain financial resources. Referring to Table 4, a total of 150 respondents 
INTERNATIONAL JOURNAL OF ACADEMIC RESEARCH IN BUSINESS AND SOCIAL SCIENCES

Vol. 8, No. 11, Nov, 2018, E-ISSN: 2222-6990 (C) 2018 HRMARS

are looking for side income with side work and the rest of which 330 people do not do side work. So here it is concluded that not all respondents who work while studying, only some of them are spending their free time with work besides generating income to support university life.

Table 4 : : Respondents Financing Source From Part-Time Work

\begin{tabular}{ccc}
\hline \hline & Frequency & Percentage (\%) \\
\hline Yes & 150 & 31.2 \\
No & 330 & 68.8 \\
\hline Total & 480 & 100.0 \\
\hline \hline
\end{tabular}

Referring to Table 5, in case of insufficient money, a total of 327 respondents or $68.1 \%$ have savings and use their savings when in trouble. However, there were 153 respondents or $31.9 \%$ had no savings. If a problem affects them during the semester then the respondent is forced to borrow money from friends, lecturers or any of the borrowing bodies offering student loans.

\begin{tabular}{ccc} 
Table 5 : : Respondents Financing Source From Saving \\
\hline \hline & Frequency & Percentage (\%) \\
\hline Yes & 327 & 68.1 \\
No & 153 & 31.9 \\
\hline Total & 480 & 100.0 \\
\hline \hline
\end{tabular}

The findings are consistent with the findings of studies conducted by Rubayah, Hawati and Nur Ain (2015) and Mohd Fazli and Maurice (2010) which found that student's financial source comes from scholarships or loan, families, part time works and savings.

\section{CONCLUSION}

As a conclusion, the main source of students financing consists of scholarships or loans obtained from government or private bodies. In addition, respondents also receive financial assistance from families that are comprised of parents and older siblings. They also do part-time work on weekends, mid-term or semester breaks to earn income that can be used for daily expenses. Some of the respondents also have savings that can be used during an emergency time.

\section{Acknowledgement}

Higher Education Institutions (UPSI, UTP, UMP, UCSI TERENGGANU, UPM, UNITEN, UTEM, MMU MELAKA).

\section{Corresponding Author}

Norhaslinda Daud

Universiti Pendidikan Sultan Idris, 35900 Tg Malim, Perak, Malaysia

Norhaslinda.daud88@gmail.com 
INTERNATIONAL JOURNAL OF ACADEMIC RESEARCH IN BUSINESS AND SOCIAL SCIENCES

Vol. 8, No. 11, Nov, 2018, E-ISSN: 2222-6990 (C) 2018 HRMARS

\section{References}

Haslina H., Naimah I., \& Hamzan H. (2013). Kajian Terhadap Pengurusan Wang Perbadanan Tabung Pendidikan Tinggi Nasional (PTPTN) Dalam Kalangan Pelajar Semester Enam Politeknik Tuanku Sultanah Bahiyah, Jabatan Pengajian Am Politeknik Tuanku Sultanah Bahiyah, Kulim, Kedah.

Jabatan Perkhidmatan Awam (JPA). (2017). Accessed on 20 February 2017 from http://www.jpa.gov.my.

Kementerian Pendidikan Malaysia (KPM). (2017). Accessed on 20 February 2017 from http://www.moe.gov.my.

Kirkpatrick, L. A. \& Feeney, B. C. (2005). A Simple Guide to SPSS for Windows, Version 12.0 and 13.0. Wadsworth Publishing.

Krejcie, R. V. \& Morgan, D. W. (1970). Determining Sample Size for Research Activities. Educational and Psychological Measurement, 30, 607-610.

Lilawati, A. W. (2013). Aplikasi Prinsip Pemuliharaan Terhadap Kerja Penyesuaigunaan Bangunan Bersejarah Sebagai Hotel di Tapak Warisan Dunia UNESCO Melaka \& George Town oleh Universiti Sains Malaysia.

Majlis Amanah Rakyat (MARA). (2017). Accessed on 21 February 2017 from http://www.mara.gov.my.

Malayan Banking Berhad. (2017). Accessed on 21 February 2017 from http://www.maybank2u.com.my.

Mohamad Fazli, S., \& Maurice, M. D. (2010). Savings Behavior and Financial Problems Among College Students: The Role of Financial Literacy in Malaysia. Cross-Cultural Communication, 6(3), 103-110.

Perbadanan Tabung Pendidikan Tinggi Nasional (PTPTN). (2016). Pelan Strategik PTPTN 20162020. Accessed on 20 September 2016 from http://www.ptptn.gov.my.

Perbadanan Tabung Pendidikan Tinggi Nasional (PTPTN). (2017). Accessed on 1 February 2017 from http://www.ptptn.gov.my.

Rubayah, Y., Hawati, J., \& Nur Ain, K. (2015). Tahap Literasi Kewangan dalam Kalangan Pelajar Universiti Awam: Kajian di Universiti Kebangsaan Malaysia. Jurnal Personalia Pelajar, 18(1), 75-88.

Sarah, A. S., Aisyah, A. R., \& Hairunnizam, W. (2015). Pola Perbelanjaan dan Haddul Kifayah Zakat bagi Pelajar Sarjana Muda di Universiti Kebangsaan Malaysia. Jurnal Personalia Pelajar 18(2), 45-62.

Suhaila, N., Rabi'atul, 'A. S. N., Nuzul, A. B., \& Siti, S. A. R. (2016). Faktor yang Mendorong Mahasiswa IPT Membuat Kerja Sambilan. Proceeding of the $2^{\text {nd }}$ International Conference On Economics \& Banking 2016 (2nd ICEB). 